\title{
Nutritional Quality of Moringa oleifera Seeds and Physicochemical Properties of Its Crude Oil
}

\author{
Milson S. Barbosa ${ }^{1,2}$, Cintia C.C. Freire ${ }^{1,2}$, Danyelle A. Mota ${ }^{1,2}$, Lays C. Almeida' ${ }^{1,2}$, Ranyere L. Souza ${ }^{1,2}$, Matheus M. \\ Pereira $^{3}$, Álvaro S. Lima ${ }^{1,2}$, Cleide M. F. Soares ${ }^{1,2^{*}}$ \\ ${ }^{1}$ Tiradentes University (UNIT), Aracaju, Sergipe; ${ }^{2}$ Institute of Technology and Research (ITP); Aracaju, Sergipe, Brazil; \\ ${ }^{3}$ University of Aveiro, CICECO - Aveiro Institute of Materials, Department of Materials and Ceramic Engineering; \\ Aveiro, Portugal
}

\begin{abstract}
This study aimed to evaluate the centesimal composition of Moringa oleifera Lam seeds and identify the physicochemical properties of crude oil extracted from Moringa oleifera Lam seeds. The values found for the centesimal composition showed that the seeds are constituted by $41 \%$ of crude oil, $32.40 \%$ of proteins, $4.20 \%$ of ash, $19.54 \%$ of carbohydrate, and $2.86 \%$ of moisture. These results indicate that Moringa oleifera Lam seeds are a potential source for health and diet food products. Compared with oils from Moringa oleifera Lam seeds grown in other countries, the physicochemical characteristics found in the oil are in agreement with data from the literature. Therefore, Moringa oleifera Lam oil can be used as a potential source for the manufacture of several industrial products, such as food and cosmetics.
\end{abstract}

Keywords: Moringa oleifera Lam. Seeds. Vegetable Oil. Physicochemical Properties.

Abbreviations: ANVISA: Agência Nacional de Vigilância Sanitária; TGA: thermogravimetric analysis; FTIR: Fourier transform infrared spectroscopy.

\section{Introduction}

Moringa oleifera Lam (Moringa oleifera Lamarck) is a species that belongs to the Moringaceae family, popularly known as Moringa, White-lily, or Okra of quina [1]. Originally from northern India, Moringa oleifera Lam is widely distributed in different tropical regions of the world and was introduced in Brazil in 1950. Due to high adaptability in nutrient-poor soils, this specimen was spread in several regions worldwide, such as the Brazilian northeast $[2,3]$.

Moringa oleifera Lam is considered to be one of the most cultivated plants in the world and as an adult, it can produce annually 3 to 5 tons of seeds per hectare [4]. Several health benefits were reported as a result of supplementation with Moringa oleifera Lam seeds [5]. The mature seeds are rich in lipids, which represent between

Received on 13 September 2020; revised 28 September 2020. Address for correspondence: Cleide Mara Faria Soares, Tiradentes University, Institute of Technology and Research, Av. Murilo Dantas, 300, Zip Code: 49032-971, Aracaju, SE, Brazil. Phone: +55 (79) 32182190. Fax: +55 (79) 32182190 . E-mail address: cleide18@yahoo.com.br

J Bioeng. Tech. Appl. Health 2020;3(4):341-346.

(C) 2020 by SENAI CIMATEC. All rights reserved.
$22 \%$ and $42 \%$ of their total weight [6]. The oil extracted from the seeds of Moringa oleifera Lam has a fatty acid profile similar to olive oil, and has been considered one of its substitutes as a functional food. Additionally, high-stability frying has enhanced its use as cooking oil in different regions of the world [7,8]. Moringa oleifera Lam oil has also been used as a raw material for the manufacture of cosmetics and biofuels [3]. However, due to the lack of studies in the literature on the nutritional quality and safety of Moringa oleifera Lam, the Agência Nacional de Vigilância Sanitária (ANVISA) banned the marketing and use of products containing Moringa oleifera Lam in Brazil. The industrial application of vegetable oils requires an analysis of seeds conservation status, as well as the physicochemical properties of oil extracted [9]. However, detailed information on the centesimal composition and physicochemical properties of oil extracted from Moringa oleifera Lam seeds is lacking.

In this study, the centesimal composition seeds (lipids, proteins, ash, carbohydrates, and moisture) and physicochemical properties (acid value, free fatty acid content, iodine value, saponification value, peroxide value, density, kinematic viscosity, and refractive index) of oil extracted from Moringa oleifera Lam seeds were 
studied. Also, the extracted oil was analyzed by Fourier transform infrared spectroscopy (FTIR) and thermogravimetric analysis (TGA/DTA).

\section{Materials and Methods}

\section{Moringa oleifera Lam Seeds}

The seeds of Moringa oleifera Lam were collected in Tiradentes University, located in Aracaju, Sergipe, Brazil. The seeds were removed from the pod, selected, ground in a domestic blender, and sieved to reach a particle size of 60 mesh.

Centesimal Composition of Moringa oleifera Lam $\underline{\text { Seeds }}$

The centesimal composition of Moringa oleifera Lam seeds was determined by moisture, ash, lipids, proteins, and carbohydrate contents, according to the Official Methods of Analysis of AOAC International [10]. The determinations were performed in triplicate and expressed as mean values and standard deviation.

\section{Extraction of Moringa oleifera Lam Oil}

The oil from $50 \mathrm{~g}$ of ground Moringa oleifera Lam seeds was extracted with n-hexane using a Soxhlet apparatus for $8 \mathrm{~h}$ at $68^{\circ} \mathrm{C}$. Then, the solvent was removed from oil using a rotary evaporator (IKA, RV 10 Control). Finally, the oil was ovendried at $60^{\circ} \mathrm{C}$ to completely remove all residual solvent traces.

\section{Characterizations of Moringa oleifera Lam Oil}

The physicochemical properties: acid value, free fatty acid content, iodine value, saponification value, peroxide value, density, kinematic viscosity, and refractive index, were determined according to standard analytical methods recommended by Official Methods of Analysis of AOAC International [10].
Fourier transform infrared spectroscopy (FTIR) spectrum of Moringa oleifera Lam oil was recorded on a Cary 630 FTIR spectrometer (Agilent Technologies, Germany). The spectrum was measured in a spectral range from 4000 to $650 \mathrm{~cm}^{-1}$ and at a spectral resolution of $4 \mathrm{~cm}^{-1}$ and 32 scans. Thermogravimetric analysis was carried in Shimadzu DTG-60H simultaneous DTATGA apparatus out in synthetic air. The Moringa oleifera Lam oil ( $5 \mathrm{mg}$ ) was heated from 25 to $600^{\circ} \mathrm{C}$ at a rate of $10^{\circ} \mathrm{C} \mathrm{min}{ }^{-1}$ with a gas flow rate of $50 \mathrm{~mL} \mathrm{~min}^{-1}$.

\section{Results and Discussion}

Centesimal Composition of Moringa oleifera Lam Oil

The nutritional value of seeds depends on the centesimal composition of dry mass, especially the content of proteins. Therefore, the centesimal composition of Moringa oleifera Lam seeds after grinding and sieving is presented in Table 1. As it can be seen, the nutritional composition of Moringa oleifera Lam seeds (on a dry basis), was $2.86 \% \pm 0.3$ for moisture, $14.20 \% \pm 0.2$ for ash, $41.00 \% \pm 0.2$ for lipids, $32.40 \% \pm 0.8$ for proteins, and $19.54 \% \pm 1.3$ for carbohydrates, which are in agreement with previous studies reported $[11,12]$. The small variability may be due to different local growing conditions (type and $\mathrm{pH}$ of soil) and climatic conditions (temperature and time of year). In short, these results suggest that Moringa oleifera Lam seeds are a source of nutrients that can be used to supplement diets.

\section{Characterizations of Moringa oleifera Lam Oil}

Table 2 summarizes the physicochemical properties of Moringa oleifera Lam oil extracted and reported by different authors. The acid value of Moringa oleifera Lam oil was $21.41 \mathrm{mg}_{\mathrm{KOH}} / \mathrm{g}$, similar to acid values reported in the literature $[3,8]$. The high acidity index obtained indicates that oil has undergone hydrolysis of triacylglycerol chains, 
Table 1. Centesimal composition of Moringa oleifera Lam seeds.

\begin{tabular}{lccc}
\hline $\begin{array}{l}\text { Centesimal } \\
\text { composition }\end{array}$ & Determined values & $\begin{array}{r}\text { Abiodun and cols. } \\
(\mathbf{2 0 1 2})[\mathbf{1 1}]\end{array}$ & $\begin{array}{c}\text { Bridgemohan and cols. } \\
(\mathbf{2 0 1 4})[\mathbf{1 2}]\end{array}$ \\
\hline Moisture (\%) & $2.86 \pm 0.3$ & 4.7 & 5.4 \\
Ash (\%) & $4.20 \pm 0.2$ & 4.1 & 3.7 \\
Lipids (\%) & $41.00 \pm 0.2$ & 45.8 & 38.2 \\
Proteins (\%) & $32.40 \pm 0.8$ & 28.0 & 37.2 \\
Carbohydrates $(\%)$ & $19.54 \pm 1.3$ & 18.3 & 15.5 \\
\hline
\end{tabular}

Values are mean \pm SD of triplicate determinations.

Table 2. Physicochemical properties of oil extracted from Moringa oleifera Lam seeds.

\begin{tabular}{lccc}
\hline Properties & Determined values & $\begin{array}{c}\text { Bhutada } \\
\text { and cols. [15] }\end{array}$ & $\begin{array}{c}\text { Pereira } \\
\text { and cols. [13] }\end{array}$ \\
\hline Acid value $\left(\mathrm{mg}_{\mathrm{KOH}} / \mathrm{g}\right)$ & $21.41 \pm 0.86$ & 26.22 & 20.50 \\
Free fatty acid $\left(\mathrm{mg}_{\mathrm{KOH}} / \mathrm{g}\right)$ & $10.70 \pm 0.86$ & 13.11 & 10.25 \\
Iodine value $\left(\mathrm{gI}_{2} / 100 \mathrm{~g}\right)$ & $72.64 \pm 1.24$ & 75.06 & 70.70 \\
Saponification value $\left(\mathrm{mg}_{\mathrm{KOH}} / \mathrm{g}\right)$ & $181.99 \pm 2.62$ & 172.16 & 179.40 \\
Peroxide value $\left(\mathrm{meqO}_{2} / \mathrm{kg}\right)$ & $3.98 \pm 0.26$ & $\mathrm{ND}$ & 5.40 \\
Density at $15^{\circ} \mathrm{C}\left(\mathrm{kg} / \mathrm{m}^{3}\right)$ & $894.5 \pm 5.51$ & 240 & 907.20 \\
Kinematic viscosity at $40^{\circ} \mathrm{C}(\mathrm{cSt})$ & $40.32 \pm 0.28$ & $\mathrm{ND}$ & 39.10 \\
Refractive index & $1.45 \pm 0.04$ & $\mathrm{ND}$ & $\mathrm{ND}$ \\
Water content $(\%)$ & $0.35 \pm 0.02$ & $\mathrm{ND}$ & $\mathrm{ND}$ \\
\hline
\end{tabular}

Values are mean $\pm \mathrm{SD}$ of triplicate determinations.ND $=$ not determined.

releasing free fatty acids. The determination of iodine index is a useful measure for understanding the degree of oil unsaturation and is directly related to their oxidative stability [14]. The average value obtained (72.64 $\left.\mathrm{gI}_{2} / 100 \mathrm{~g}\right)$ is not significantly different from values reported by other authors $[13,15]$. Saponification index was $181.99 \mathrm{mg}_{\mathrm{KOH}} / \mathrm{g}$, within the expected range for vegetable oil seeds or saponifiable animals (180 and $200 \mathrm{mg}_{\mathrm{KOH}} / \mathrm{g}$ ) [13]. The peroxide value was $3.98 \mathrm{meqO}_{2} / \mathrm{kg}$, which indicates high resistance to oxidation of Moringa oleifera Lam oil [16].

In the evaluation of physical properties, refraction index was 1.45 , whereas density at $15^{\circ} \mathrm{C}$ amounted to $894.5 \mathrm{~kg} / \mathrm{m}^{3}$ and kinematic viscosity at $40^{\circ} \mathrm{C}$ was $40.32 \mathrm{cSt}$. These values are consistent with the requirements of the standard for vegetable oils [17]. The content of water in oil determined using Karl Fischer method amounted to $0.35 \%$. This low moisture content may be related to seed storage or interaction with the solvent during the oil extraction process. The variations observed in Table 2 can be attributed to the different climatic conditions of plant cultivation, stage of ripeness and time of seed harvest.

Figure 1 shows FTIR spectrum used to analyze the main functional groups present in the oil extracted from Moringa oleifera Lam seeds. The absence of a peak after $3000 \mathrm{~cm}^{-1}$ indicates very low concentrations of impurities contained in hydroxyl groups $(\mathrm{OH})$, such as free glycerol and water [18], which corroborates the moisture data 
Figure 1. FTIR spectra of Moringa oleifera Lam oil.

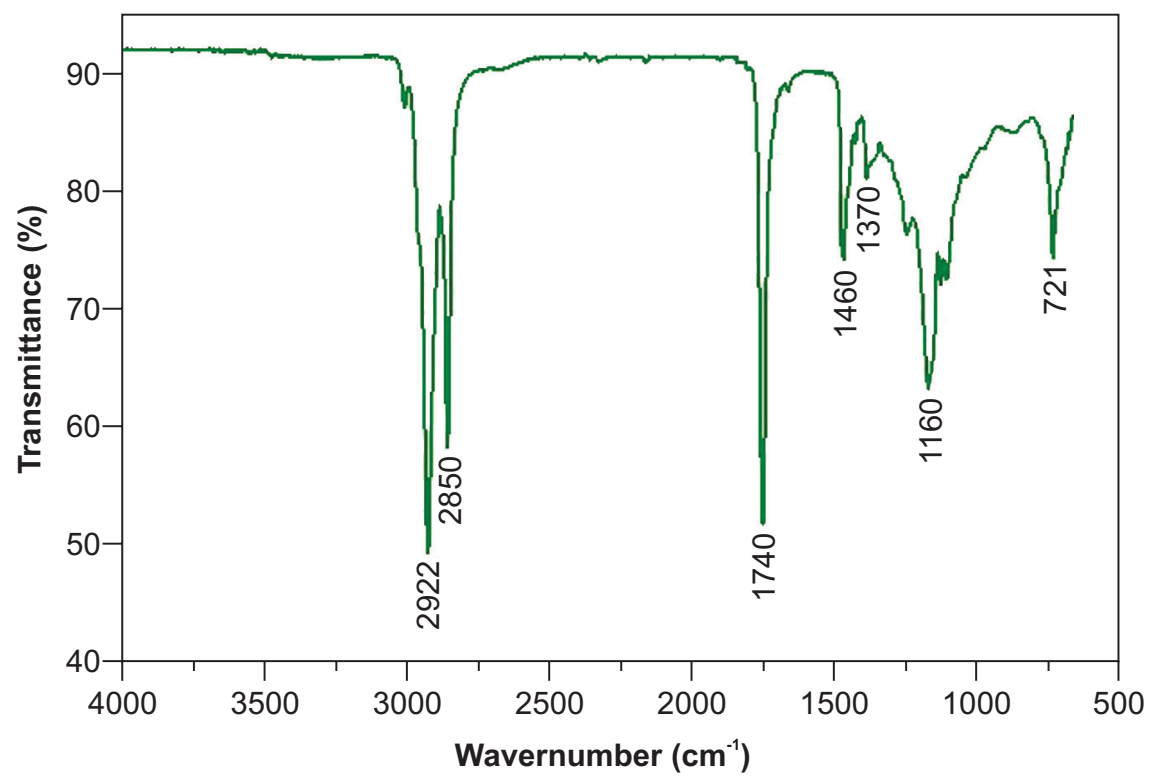

$(0.35 \%)$ obtained in this study. There is a wide band from 2922 to $2850 \mathrm{~cm}^{-1}$, due to the symmetrical and asymmetric elongation of the $\mathrm{C}-\mathrm{H}$ group, attributed to the fatty acids present in the oil [19]. In the region between 1770 and $660 \mathrm{~cm}^{-1}$, there are intense bands attributed to the elongation of the $\mathrm{C}=\mathrm{O}$ bond, a characteristic carbonyl group of proteins and fatty acid structures. The peak in the region 1460-1370 $\mathrm{cm}^{-1}$ indicates the presence of $\mathrm{C}-\mathrm{C}$. The peaks at 1160 and $721 \mathrm{~cm}^{-1}$ are assigned to $\mathrm{C}-\mathrm{O}$ bonds and the asymmetric deformation of $\mathrm{CH}_{2}$ group present in fatty acids, respectively [19]. The presence of these groups suggests the potential of crude oil from Moringa oleifera Lam for the manufacture of several bioproducts, such as food and cosmetics [3].

The thermogravimetric curve and its derivative (TGA/DTA) show the volatilization and/or thermal combustion of $100 \%$ of the mass of the oil in three thermal stages (Figure 2). The first stage, starting at approximately $30^{\circ} \mathrm{C}$ and finishing at $181^{\circ} \mathrm{C}$, where a loss of mass of $0.38 \%$ is associated with the volatilization of the water contained in the oil. The second stage occurred between temperatures 181 and $405^{\circ} \mathrm{C}$ with weight loss equal to $93.03 \%$. In this stage, the greater decomposition indicates the decomposition of fatty acids in the oil, for example, oleic acid, which has a boiling point of $360^{\circ} \mathrm{C}$. The third stage is associated with the decomposition of the existing impurities in the oil constituents, showed a weight loss of $6.54 \%$ at temperatures between $405^{\circ} \mathrm{C}$ and $500^{\circ} \mathrm{C}$ [20]. In short, thermal analysis shows the potential of Moringa oleifera Lam oil for frying due to its high thermal stability.

\section{Conclusion}

In this study, the centesimal composition of Moringa oleifera Lam seeds and physicochemical properties of oils from Moringa oleifera Lam seeds were identified. In Moringa oleifera Lam seeds the main components were lipids (41\%) and proteins (32.4\%). Thus, Moringa oleifera Lam seeds may be considered to be a good and safe source to supplement daily nutrient needs could help to prevent many diseases. The physicochemical properties of oil from Moringa oleifera Lam seeds were also determined following extraction either with n-hexane. The physicochemical properties 
Figure 2. TGA (-) and DTA (---) curves of Moringa oleifera Lam oil.

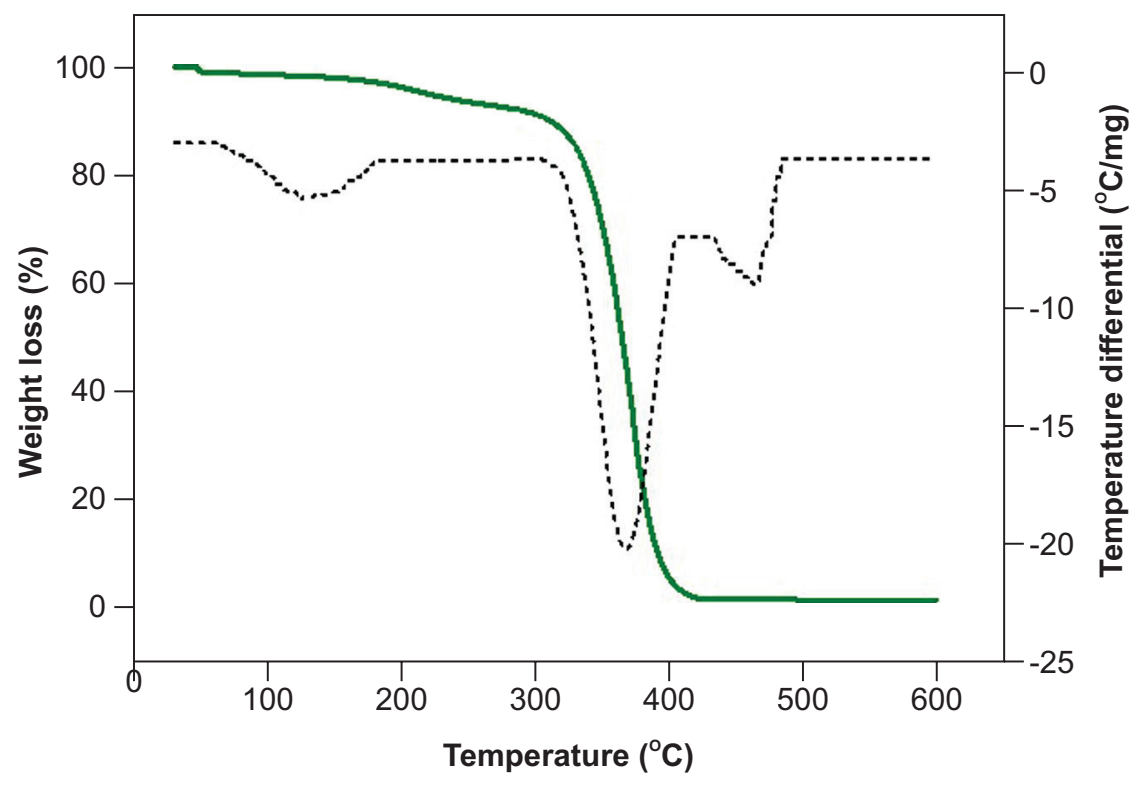

of crude oil from Moringa oleifera Lam seeds showed that it can be a source of fatty acids for food and cosmetics production.

\section{Acknowledgments}

This study was financed in part by Coordenação de Aperfeiçoamento de Pessoal de Nível Superior [CAPES] - Finance Code 001; Conselho Nacional de Desenvolvimento Científico e Tecnológico [CNPq]; and Fundação de Apoio à Pesquisa e à Inovação Tecnológica do Estado de Sergipe [FAPITEC/SE].

\section{References}

1. Nadeem M, Imran M. Promising features of Moringa oleifera oil: Recent updates and perspectives. Lipids Health Dis 2016.

2. Ogunsina BS, Indira TN, Bhatnagar AS, Radha C, Debnath S, Gopala KA. Quality characteristics and stability of Moringa oleifera seed oil of Indian origin. J Food Sci Technol 2014;51:503-10.

3. Leone A, Spada A, Battezzati A, Schiraldi A, Aristil J, Bertoli S. Cultivation, genetic, ethnopharmacology, phytochemistry and pharmacology of Moringa oleifera leaves: An overview. Int J Mol Sci 2015;16:12791-835.
4. Gopalakrishnan L, Doriya K, Kumar DS. Moringa oleifera: A review on nutritive importance and its medicinal application. Food Sci Hum Wellness 2016;5:49-56.

5. Leone A, Spada A, Battezzati A, Schiraldi A, Aristil J, Bertoli S. Moringa oleifera seeds and oil: Characteristics and uses for human health. Int J Mol Sci 2016.

6. Saini RK, Sivanesan I, Keum YS. Phytochemicals of Moringa oleifera: a review of their nutritional, therapeutic and industrial significance. 3 Biotech 2016;6:1-14.

7. Sengupta A, Gupta MP. Studies on the Seed Fat Composition of Moringaceae family. Fette, Seifen, Anstrichm 1970.

8. Oliveira JTA, Silveira SB, Vasconcelos IM, Cavada BS, Moreira RA. Compositional and nutritional attributes of seeds from the multiple purpose tree Moringa oleifera Lamarck. J Sci Food Agric 1999.

9. Belgacem MN, Gandini A. Materials from vegetable oils: major sources, properties and applications. Monomers, Polym Compos from Renew Resour 2008:39-66.

10. Association of the Official Analytical Chemists (AOAC). Official Methods of Analysis of AOAC International - 20 ${ }^{\text {th }}$ Edition, 2016. 20th Ed Gaithersbg AOAC 2016.

11. Abiodun O, Adegbite J, Omolola O. Chemical and physicochemical properties of Moringa flours and oil. Glob J Sci Front Res 2012. 
12. Bridgemohan P, Bridgemohan R, Mohamed M. Chemical composition of a high protein animal supplement from Moringa oleifera. African J Food Sci Technol 2014.

13. Pereira F, Schuler A, Galvão C, Filho N, Silva V. Turbidity and acidity as monitoring parameters in the purification of Moringa oleifera oil for biodiesel production. Am Chem Sci J 2016;16:1-9.

14. Sánchez-Machado DI, López-Cervantes J, LópezHernández J, et al.. Effect of the refining process on Moringa oleifera seed oil quality. Food Chem 2015;187:53-7.

15. Bhutada PR, Jadhav AJ, Pinjari D V., Nemade PR, Jain RD. Solvent assisted extraction of oil from Moringa oleifera Lam seeds. Ind Crops Prod 2016;82:74-80.

16. Rahman IM, Barua S, Rahman MA, Hasegawa H. Physicochemical properties of Moringa oleifera Lam seed oil of the indigenous-cultivar of Bangladesh. J Food Lipids 2009;16:540-53.
17. Codex Alimentarius. Standard for Named Vegetable Oils. CODEX STAN 210-1999 (Ammended 2015) 2015.

18. Ivanoiu A, Schmidt A, Peter F, Rusnac LM, Ungurean M. Comparative study on biodiesel synthesis from different vegetables oils. Chem Bull Univ (Timisoara) 2011;56:94-8.

19. Araújo CST, Alves VN, Rezende HC, Almeida ILS, De Assunção RMN, Tarley CRT. Characterization and use of Moringa oleifera seeds as biosorbent for removing metal ions from aqueous effluents. Water Sci Technol 2010;62:2198-203.

20. Rashid U, Anwar F, Ashraf M, Saleem M, Yusup S. Application of response surface methodology for optimizing transesterification of Moringa oleifera oil: Biodiesel production. Energy Convers Manag 2011;52:3034-42. 